\title{
Effects of Cultivation Systems and Environmental Conditions on Peppermint (Mentha $\times$ piperita L.) Biomass Yield and Oil Content
}

\author{
Camelia OROIAN ${ }^{1}$, Ilie COVRIG ${ }^{1 *}$, Antonia ODAGIU², \\ Cristian MĂLINAȘ ${ }^{2}$, Cristina MOLDOVAN², Andrei FLEȘERIU ${ }^{1}$
}

\author{
${ }^{1}$ University of Agricultural Sciences and Veterinary Medicine Cluj-Napoca, Faculty of Horticulture, 3-5 Calea Mănăștur, 400372 Cluj-Napoca, \\ Romania; cameliaforoian@gmail.com;ilie_covrig@yahoo.com (*correspondingauthor); andrei_fleseriu@yahoo.com \\ ${ }^{2}$ University of Agricultural Sciences and Veterinary Medicine Cluj-Napoca, Faculty of Agriculture, 3-5 Calea Mănăștur, 400372 Cluj-Napoca, \\ Romania; antonia.odagiu@usamvcluj.ro; cristian.malinas@usamvclu.ro; cristina.moldovan@usamvcluj.ro
}

\begin{abstract}
Peppermint (Mentha $\times$ piperita L.) is perennial plant cultivated for essential oil production. In the present study, field experiments were conducted to determine the performance of peppermint under different cultivation systems for two consecutive growing periods in 2015 and 2016. The effects of environmental conditions on peppermint biomass yield and oil content was also evaluated. The experiments were carried out according to randomized complete block design with five replications per cultivation system. The results of the present study indicate that the total aboveground dry weight and dry leaves biomass were affected by cultivation system and year. For both growing seasons, the highest values were found under the conventional farming system. In contrast, oil content was approximately $14 \%$ higher in organic system than in conventional system. Moreover, oil content differed by year, with higher values being observed in 2015 comparing to 2016. Both oil content and biomass yield were positively affected by high temperatures. The results from this study demonstrated that both environmental conditions and the cultivation systems affect the biomass and oil content in peppermint crop.
\end{abstract}

Keywords: aromatic plants, climate conditions, farming systems, precipitation, temperature, yield.

\section{Introduction}

Peppermint (Mentha $\times$ piperita L.) is perennial plant cultivated around the world for essential oil production (Karkanis et al., 2017). According to Capuzzo and Mafei (2016), peppermint is a hybrid between water mint (Mentha aquatica L.) and spearmint (Mentha spicata L.). The last report of FAOSTAT on peppermint production (FAO, 2014), emphasize an increasing trend in the world peppermint production, which, in 2014 was 92,295 tons, over 3-fold bigger than world production in $1990(28,672$ tons). Moreover, in the last 24 years, an increase of about $70 \%$ in the cultivated area was registered. The major contributor to world peppermint production is Asia with $92.23 \%$ of total production and is followed by Americas, which contributes $7.61 \%$.

Peppermint is one of the most important medicinal plants. Various studies have reported the health benefits of peppermint and other mint species (Dorman et al., 2003; McKay and Blumberg, 2006; Barbalho et al., 2011;
Meamarbashi and Rajabi, 2013; Meamarbashi, 2014; Balakrishnan, 2015). Peppermint can also be used as nutritional supplement in livestock feed (Hosoda et al., 2005), while the essential oils and its components are used for the control of various pests (insects, bacteria and fungi) in crops (Montes-Belmont and Carvajal, 1998; Ibrahim et al., 2001; Imai et al., 2001). Menthol (26-30\%), menthone $(14-21 \%)$ and menthofuran $(5-11 \%)$ are the main components of peppermint essential oil (Zheljazkov et al., 1999). Several other constituents such as isomenthone, eucalyptol, pulegone, limenone, 3-octanol are also present (Chialva et al., 1993; Zheljazkov et al., 2009).

Several studies have been conducted to evaluate the effects of various cultivation practices (i.e. intercropping, irrigation, herbicides, fertilization) on growth, yield and quality of peppermint (Singh et al., 1989; Jeliazkova et al., 1999; Zheljazkov et al., 1999; Verna et al., 2013; Karkanis et al., 2017; Németh-Zámbori et al., 2017). In contrast, a limited number of studies have been published about the effects of environmental conditions on growth and yield of peppermint crop (Clark and Menary, 1980; Piccaglia et al., 
1993; Rita and Animesh, 2011). Therefore, this study has been carried out: (1) to determine the performance of peppermint under organic or conventional cultivation systems and (2) to evaluate the effects of environmental conditions (temperature and precipitation) on peppermint biomass yield and oil content in Southeastern Europe.

\section{Materials and Methods}

\section{Study site and experimental design}

A peppermint crop (Mentha $\times$ piperita L.) crop was established at an experimental field located in the Alba Iulia region in Romania $\left(46^{\circ} 04^{\prime} 17^{\prime \prime} \mathrm{N}\right.$, and $\left.23^{\circ} 34^{\prime 2} 23^{\prime \prime} \mathrm{E}\right)$. The soil was sandy clay loam (35\% sand, $30 \%$ silt and, $45 \%$ clay), with $\mathrm{pH}$ 7.2. Peppermint was transplanted in the autumn (October) of 2014 in rows $20 \mathrm{~cm}$ apart and within the rows at $70 \mathrm{~cm}$. The experiment was conducted for two consecutive growing periods (April-July), in 2015 and 2016. Meteorological data (temperature, wind velocity and precipitation) are presented in Table 1 .

The experiment was set up over an area of $150 \mathrm{~m}^{2}$. Completely randomized block design was used in both years, with five replicates per treatment. The plot size was 10 x $5 \mathrm{~m}\left(50 \mathrm{~m}^{2}\right)$. The experimental treatments were as follows: Control, without agricultural inputs; ORG: organic cultivation system; and $\mathrm{CON}$ : conventional cultivation system. In organic cultural system, $2000 \mathrm{~kg} \mathrm{ha}^{-1}$ of sheep manure was applied, while no herbicide application was made. The plots were kept weed free by hand weeding. The peppermint cultivation in organic system was conducted according to principles of Council Regulations (EC) No $834 / 2007$ of 28 June 2007 on organic production and labelling of organic products and repealing Regulation (EEC) No 2092/91. In addition, in conventional system, $210 \mathrm{~kg} \mathrm{ha}^{-1}$ of an inorganic fertilizer $\left(\mathrm{N}: \mathrm{P}_{2} \mathrm{O}_{5}: \mathrm{K}_{2} \mathrm{O}\right.$, ratio 15:15:15) was applied, while fluazifop-p-butyl (Fusilade Forte; Syngenta, Romania) was applied post-emergence at a rate of $0.195 \mathrm{~kg}$ a.i. ha ${ }^{-1}$ to control the grass weeds, in April. Broad-leaved weeds were controlled by hand weeding.

\section{Sampling, measurements and methods}

To determine the total aboveground dry weight and the dry leaves biomass, peppermint crop was harvested on the 15 July 2015 and the 15 July 2016. An area of $1 \mathrm{~m}^{2}$ from each plot was hand harvested. Then, the dry weight was determined after drying at $60^{\circ} \mathrm{C}$ until constant weight. For the extraction of the essential oil, plant samples were airdried at room temperature in the shade. The essential oil was extracted via the Hydro steam-distillation method using a Clevenger type apparatus, according to AOAC methodology (2005). The distillation was repeated until oil recovery stopped. The extraction was performed thrice for each plot. After the extraction, the oil was separated from the water phase. The oil content was expressed as percentage $(\mathrm{v} / \mathrm{w})$ of peppermint dry weight. Final, the oil yield was also measured using the equation: Oil yield $\left(\mathrm{L} \mathrm{ha}^{-1}\right)=(\mathrm{OC} \times$ $\mathrm{DLB}) / 100$, where DLB is the dry leaves biomass $\left(\mathrm{kg} \mathrm{ha}^{-1}\right)$ and OC is the oil content $(\mathrm{ml} / 100 \mathrm{~g})$.

Table 1. Mean monthly temperature $\left({ }^{\circ} \mathrm{C}\right)$, wind velocity $\left(\mathrm{m} \mathrm{s}^{-1}\right)$, and precipitation $(\mathrm{mm})$ at the experimental site during the two growing seasons (November 2014 to July 2015 and November 2015 to July 2016)

\begin{tabular}{|c|c|c|c|c|c|}
\hline $1^{\text {st }}$ Growing period & $\begin{array}{c}\text { Mean Temperature } \\
\left({ }^{\circ} \mathrm{C}\right)\end{array}$ & $\begin{array}{c}\text { Min temperature } \\
\left({ }^{\circ} \mathrm{C}\right)\end{array}$ & $\begin{array}{c}\text { Max temperature } \\
\left({ }^{\circ} \mathrm{C}\right)\end{array}$ & $\begin{array}{l}\text { Wind velocity } \\
\qquad\left(\mathrm{m} \mathrm{s}^{-1}\right)\end{array}$ & $\begin{array}{l}\text { Precipitation } \\
(\mathrm{mm})\end{array}$ \\
\hline November 2014 & 5.83 & -4.00 & 14.00 & 6.03 & 23.35 \\
\hline December 2014 & 1.90 & -18.00 & 8.00 & 7.87 & 34.27 \\
\hline January 2015 & -0.71 & -18.00 & 9.00 & 9.39 & 18.53 \\
\hline February 2015 & 0.32 & -6.00 & 9.00 & 6.86 & 192.00 \\
\hline March 2015 & 4.68 & -2.00 & 13.00 & 7.71 & 34.29 \\
\hline April 2015 & 8.90 & 2.00 & 17.00 & 10.43 & 39.88 \\
\hline May 2015 & 15.87 & 9.00 & 21.00 & 7.23 & 34.81 \\
\hline June 2015 & 18.60 & 12.00 & 23.00 & 6.90 & 44.45 \\
\hline July 2015 & 21.77 & 17.00 & 27.00 & 7.13 & 9.91 \\
\hline Mean & 8.57 & & & & \\
\hline Sum & & & & & 431.49 \\
\hline $2^{\text {nd }}$ Growing period & $\begin{array}{c}\text { Mean Temperature } \\
\left({ }^{\circ} \mathrm{C}\right)\end{array}$ & $\begin{array}{c}\text { Min temperature } \\
\left({ }^{\circ} \mathrm{C}\right)\end{array}$ & $\begin{array}{c}\text { Max temperature } \\
\left({ }^{\circ} \mathrm{C}\right)\end{array}$ & $\begin{array}{l}\text { Wind velocity } \\
\left(\mathrm{m} \mathrm{s}^{-1}\right)\end{array}$ & $\begin{array}{c}\text { Precipitation } \\
(\mathrm{mm})\end{array}$ \\
\hline November 2015 & 5.93 & 0.00 & 12.00 & 6.53 & 21.07 \\
\hline December 2015 & 0.87 & -9.00 & 7.00 & 4.94 & 5.60 \\
\hline January 2016 & -3.19 & -15.00 & 6.00 & 6.00 & 18.05 \\
\hline February 2016 & 5.69 & -1.00 & 13.00 & 9.48 & 10.41 \\
\hline March 2016 & 5.59 & 1.00 & 12.00 & 8.03 & 27.43 \\
\hline April 2016 & 12.27 & 6.00 & 18.00 & 7.80 & 70.86 \\
\hline May 2016 & 13.71 & 8.00 & 20.00 & 8.52 & 62.47 \\
\hline June 2016 & 19.73 & 15.00 & 24.00 & 7.17 & 77.46 \\
\hline July 2016 & 20.48 & 17.00 & 24.00 & 7.16 & 118.09 \\
\hline Mean & 8.38 & & & & \\
\hline Sum & & & & & 411.44 \\
\hline
\end{tabular}


578

\section{Statistical analysis}

Analysis of variance (ANOVA) was conducted for all data to evaluate the effects of cultural systems, the year effects and the interactions between them. Data are presented in tables as means $(n=5)$. Differences between means were separated by Fisher's Least Significant Difference (LSD) test at $\mathrm{p} \leq 0.05$ level. Statistical analysis was performed using the STATISTICA software package, version 8.0 (StatSoft Inc., Tulsa, USA).

\section{Results and Discussion}

The lowest mean monthly temperature of both growing periods are recorded in January $\left(-0.71{ }^{\circ} \mathrm{C}\right.$ in 2015 , and -3.19 ${ }^{\circ} \mathrm{C}$ in 2016), and highest in July $\left(21.77^{\circ} \mathrm{C}\right.$ in 2015 , and $20.48^{\circ} \mathrm{C}$ in 2016), months when we also report minimum, and maximum daily values (Table 1). By entire experimental period, the highest mean wind velocity is reported in April $2015(10.43 \mathrm{~m} / \mathrm{s})$, while the lowest in December $2015(4.94 \mathrm{~m} / \mathrm{s})$. A bigger sum of precipitations, $431.49 \mathrm{~mm}$, respectively, characterize the first growing period, compared to the second, when sum of precipitations was in amount of $411.44 \mathrm{~mm}$ (Table 1).

Concerning the dry leaves biomass there were significant differences between cultivation systems (Table 2). For both growing seasons, significant differences between cultivation systems were recorded. In the first growing season, the highest dry leaves biomass (917 kg ha ${ }^{-1}$ ) was found under the conventional farming system. For the second growing season, the lowest dry leaves biomass was recorded in organic plots $\left(959 \mathrm{~kg} \mathrm{ha}^{-1}\right)$.

The total aboveground dry weight was also affected by cultivation system. In the first growing season, the highest values $\left(2375 \mathrm{~kg} \mathrm{ha}^{-1}\right)$ were recorded in the conventional system and the lowest in organic cultural system (Table 2). Total biomass yield was comparable to those reported in the Mediterranean basin by Karkanis et al. (2017). Total aboveground dry weight of peppermint was approximately $25 \%$ higher than in conventional system than in organic system. Significant differences in total aboveground dry weight were also recorded in the second growing period. The highest total aboveground dry weight was found in conventional plots. Moreover, total aboveground dry weight differed by year, with higher values being observed in 2016 comparing to 2015. In contrast, Karkanis et al. (2017) have also reported that biomass yield of peppermint affected by year and the highest values were recorded during the first growing season in comparison to the second growing period. Similarly, Piccaglia et al. (1993) have also found lower biomass yield in the second growing season, compared with yield obtained in the first growing season.

Whatever cultivation system, both aboveground dry weight, and dry leaves biomass (Table 2)emphasize biggest values in the second cultivation period characterized by lower mean temperature $\left(8.38{ }^{\circ} \mathrm{C}\right)$, and precipitations supply $(411.44 \mathrm{~mm})$, compared to the second growing period (Table 1).

The cultivation system affected the plant height in the second growing period, November 2014 - July 2016 (Table 3). Karkanis et al. (2017), report similar plant height values in control in $2015(45.08 \mathrm{~cm})$ and fluazifop-p-butyl herbicide treatment $(42.83 \mathrm{~cm})$, as we obtained in control $(44.68 \mathrm{~cm})$, and conventional cultivation system (41.12 $\mathrm{cm})$.

Regarding the oil content, there were significant differences between cultivation systems (Table 4). In the first growing season, the highest oil content (2.23\%) was

Table 2. Total aboveground dry weight $\left(\mathrm{kg} \mathrm{ha}^{-1}\right)$ and dry leaves biomass $\left(\mathrm{kg} \mathrm{ha}^{-1}\right)$ as affected by the cultivation system, in 2015 and 2016

\begin{tabular}{ccccc}
\hline \multirow{2}{*}{ Treatments } & \multicolumn{2}{c}{ Total aboveground dry weight $\left(\mathrm{kg} \mathrm{ha}^{-1}\right)$} & 2015 & 2016 \\
\cline { 2 - 5 } & 2015 & 2016 & 822 & 1059 \\
\hline Control & 1968 & 2455 & 780 & 959 \\
ORG & 1792 & 2300 & 917 & 1255 \\
CON & 2375 & 2818 & 839 & 1091 \\
Mean & 2045 & 2524 & 8.35 & 13.81 \\
CV\% (Coefficient of variation) & 14.62 & 10.53 & 38.29 & 68.67 \\
LSD $5 \%$ & 70.84 & 130.08 & $19.878^{* * *}$ & $27.839^{* * *}$ \\
Fvalues & $99.032^{* * *}$ & $24.462^{* * *}$ & \\
\hline
\end{tabular}

RG-organic cultivation system, CON-conventional cultivation system. Means in each column followed by the some letter are not significant different according to LSD test ${ }^{* * *}$ Significant differences at $P<0.001$

Table 3. The plant height $(\mathrm{cm})$ of peppermint (Mentha $\times$ piperita) as affected by the cultivation system, in 2015 and 2016

\begin{tabular}{|c|c|c|}
\hline \multirow{2}{*}{ Treatments } & \multicolumn{2}{|c|}{ The plant height $(\mathrm{cm})$} \\
\hline & 2015 & 2016 \\
\hline Control & 39.54 & 41.12 \\
\hline ORG & 39.89 & 42.53 \\
\hline $\mathrm{CON}$ & 41.27 & 44.68 \\
\hline Mean & 39.90 & 42.78 \\
\hline CV\% (Coefficient of variation) & 3.42 & 4.19 \\
\hline $\mathrm{LSD}_{5 \%}$ & 2.05 & 0.75 \\
\hline Fvalues & $4.017^{\mathrm{ns}}$ & $37.259^{* * *}$ \\
\hline
\end{tabular}

ORG-organic cultivation system, CON-conventional cultivation system. Means in each column followed by the some letter are not significant different according to LSD test, ${ }^{\text {ns }}$ No significant differences at $P>0.05,{ }^{* * *}$ Significant differences at $P<0.001$. 
recorded in organic system and the lowest in conventional system. Oil content was approximately $14 \%$ higher in organic system than in conventional system. Karkanis et al. (2017) reported that essential oil content of peppermint varied from $1.87 \%$ to $2.11 \%$. Significant differences in oil content were also recorded in the second growing period. The highest oil content was also found in organic system. Moreover, oil content differed by year, with higher values being observed in 2015 comparing to 2016. In contrast, Karkanis et al. (2017) have found that the oil content was not affected by year.

The oil yield was also affected by cultivation system. In the first growing season, the lowest values $\left(17.39 \mathrm{~L} \mathrm{ha}^{-1}\right)$ were recorded in the conventional system and the highest in control plots (Table 5). The productivity of peppermint with respect to oil yields in this study was lower than those previously reported by Karkanis et al. (2017). Significant differences in oil yield were also recorded in the second growing period. The oil yield was also found in control plots. Moreover, oil yield differed by year, with higher values being observed in 2015 when biggest temperatures (8.57 $\left.{ }^{\circ} \mathrm{C}\right)$, and precipitations supply $(431.49 \mathrm{~mm})$, are recorded comparing to 2016. In a previous study, Duriyaparan et al.
(1987) reported that the highest leaves dry weight was produced under $30^{\circ} \mathrm{C}$ day temperatures, while Mitchell and Yang (1998) observed that both water stress and overirrigation resulting in reduced oil yield. Similarly, Khorasaninejad et al. (2011) also reported that oil content, biomass and oil yield were significantly decreased by drought stress.

The results show similar intensities of correlations between oil content (\%) and dry leaves biomass in both growing periods, 2015, and 2016, respectively (Table 6). They are moderate, with highest values in conventional cultivation system, and lowest in organic cultivation system. Reported to the same period, between oil yield $\left(\mathrm{L} \mathrm{ha}^{-1}\right)$ and dry leaves biomass moderate to strong correlations are identified, with highest values control, and lowest in organic cultivation system.

Zheljazkov et al. (2010), report moderate correlation between oil production and fresh herbage yield in flower stage $(R=0.67)$, which are similar with those obtained in our experiment in 2016, but bigger, compared to those resulted in our experiment in 2015.

Analyse of variance shows biggest influence of year on dry leaves biomass, and oil content (Table 7).

Table 4. Oil content (\% of dry weight) as affected by the cultivation system, in 2015 and 2016

\begin{tabular}{ccc}
\hline Treatments & \multicolumn{2}{c}{ Oil content (\% of dry weight) } \\
\cline { 2 - 3 } & 2015 & 2016 \\
\hline Control & $2.19 \mathrm{a}$ & $1.64 \mathrm{a}$ \\
ORG & $2.23 \mathrm{a}$ & $1.69 \mathrm{a}$ \\
CON & $1.91 \mathrm{a}$ & $1.30 \mathrm{a}$ \\
Mean & 2.11 & 1.54 \\
CV\% (Coefficient of variation) & 8.26 & 13.75 \\
LSD $\%$ & 0.14 & 0.85 \\
Fvalues & $9.043^{* * *}$ & $24.643^{* * *}$ \\
\hline
\end{tabular}

RG-organic cultivation system, CON-conventional cultivation system. Means in each column followed by the some letter are not significant different according to LSD test $(P<0.05) .{ }^{* * *}$ Significant differences at $P<0.001$

Table 5. Oil yield from peppermint leaves $\left(\mathrm{L} \mathrm{ha}^{-1}\right)$ as affected by the cultivation system, in 2015 and 2016

\begin{tabular}{ccc}
\hline Treatments & \multicolumn{2}{c}{ Oil yield $\left(\mathrm{L} \mathrm{h} \mathrm{h}^{-1}\right)$} \\
\cline { 2 - 3 } & 2015 & 2016 \\
\hline Control & $18.00 \mathrm{a}$ & $17.36 \mathrm{a}$ \\
ORG & $17.39 \mathrm{a}$ & $16.13 \mathrm{a}$ \\
CON & $17.51 \mathrm{a}$ & $16.37 \mathrm{a}$ \\
Mean & 17.63 & 16.62 \\
CV\% (Coefficient of variation) & 1.83 & 3.92 \\
LSD $5 \%$ & 1.58 & 1.64 \\
Fvalues & $5.041^{* * *}$ & $5.321^{* * *}$ \\
\hline
\end{tabular}

RG-organic cultivation system, CON-conventional cultivation system. Means in each column followed by the some letter are not significant different according to LSD test $(P<0.05) .{ }^{* * *}$ Significant differences at $P<0.001$

Table 6. The correlation matrix between dry leaves biomass yield $\left(\mathrm{kg} \mathrm{ha}^{-1}\right)$, oil content in leaves $(\%)$, and oil yield $\left(\mathrm{L} \mathrm{ha}^{-1}\right)$ as affected by the cultivation system, in 2015 and 2016

\begin{tabular}{|c|c|c|c|c|}
\hline \multirow{2}{*}{ Year } & \multirow{2}{*}{ Issue } & \multicolumn{3}{|c|}{ Dry leaves biomass $\left(\mathrm{kg} \mathrm{ha}^{-1}\right)$} \\
\hline & & Control & ORG & $\mathrm{CON}$ \\
\hline \multirow{3}{*}{2015} & Oil content $(\%)$ & 0.464 & 0.404 & 0.508 \\
\hline & Oil yield $\left(\mathrm{L} \mathrm{ha}^{-1}\right)$ & 0.668 & 0.520 & 0.623 \\
\hline & Oil content (\%) & 0.443 & 0.305 & 0.461 \\
\hline 2016 & Oil yield $\left(\mathrm{L} \mathrm{ha}^{-1}\right)$ & 0.635 & 0.566 & 0.626 \\
\hline
\end{tabular}

ORG-organic cultivation system, CON-conventional cultivation system 
Table 7. Analysis of variance for cultivation systems and year effects on total aboveground biomass, dry leaves biomass and oil content in peppermint crops

\begin{tabular}{|c|c|c|c|c|}
\hline Source & $\mathrm{df}$ & $\begin{array}{c}\text { Above ground } \\
\text { dry weight }\end{array}$ & $\begin{array}{c}\text { Dry leaves } \\
\text { biomass }\end{array}$ & $\begin{array}{c}\text { Oil } \\
\text { content }\end{array}$ \\
\hline Cultivation System & 2 & $20.266^{* * *}$ & $10.703^{* * *}$ & $6.036^{* *}$ \\
\hline Year & 1 & $47.373^{* * *}$ & $65.389^{* * *}$ & $106.667^{* * *}$ \\
\hline Cultural system $\mathrm{x}$ year & 2 & $52.621^{* * *}$ & $22.178^{* * *}$ & $82.513^{* * *}$ \\
\hline
\end{tabular}

F-test values are shown. ns: not significant; ${ }^{*},{ }^{* *},{ }^{* * *}$ denote significant differences at $P<0.05, P<0.01, P<0.001$, respectively).

The meteorological characteristics of the year, precipitation and temperature, respectively influence in a different manner dry leaves biomass and oil content. If oil content is positively influenced by higher temperatures and higher precipitations supply, the dry leaves biomass increase in growing period with lower temperature and precipitations supply. Above ground weight is influenced by both cultural system and year. Our study shows that it is advantaged by lower temperature and precipitations supply, and conventional cultivation system.

\section{Conclusions}

The results of the present study indicate that the peppermint biomass and leaves yield, and oil production was affected by both the cultural system and the environmental conditions. Significant differences in total aboveground dry weight and dry leaves between the cultivation systems were recorded for both growing seasons. The highest values were recorded in the conventional system and the lowest in organic cultural system. In contrast, the highest oil content were found in organic system and the lowest in conventional system. Moreover, the oil content was affected by year, with higher values being observed in the second growing season comparing to the first growing season. Our study also reveals that oil content and biomass yield were positively affected by high temperatures.

\section{Acknowledgements}

This research received no specific grant from any funding agency in the public, commercial, or not-for-profit sectors.

\section{References}

AOAC (2005). Official methods of analysis. Chapter 30 - Spices and other condiments. Methods of analysis. Washington: Association of Official Analytical Chemists.

Balakrishnan A (2015). Therapeutic uses of peppermint - A review. Journal of Pharmaceutical Sciences and Research 7(7):474-476.

Barbalho SM, Machado FMVF, Oshiwa M, Abreu M, Guiger EL, Tomazela P, Goulart RA (2011). Investigation of the effects of peppermint (Mentha piperita) on the biochemical and anthropometric profile of university students. Ciéncias Technologica Alimentaria Campinas 31(3):584588.

Capuzzo A, Maffei ME (2016). Molecular fingerprinting of peppermint (Mentha piperita) and some Mentha hybrids by sequencing and RFLP analysis of the $5 S$ rRNA Non-Transcribed Spacer (NTS) region. Plant Biosystems - An International Journal Dealing with all Aspects of Plant Biology 150:236-243.
Chialva F, Ariozzi A, Decastri D, Manitto P, Clementi S, Bonelli D (1993). Chemometric investigation on Italian peppermint oils. Journal of Agricultural and Food Chemistry 41:2028-2033.

Clark RJ, Menary RC (1980). Environmental effects on peppermint (Mentha piperita L.). I. Effect of day length, photon flux density, night temperature and day temperature on the yield and composition of peppermint oil. Australian Journal of Plant Physiology 7:685-692.

Council Regulations (EC) No 834/2007 (2007). Council Regulations (EC) No 834/2007 of 28 June 2007 on organic production and labelling of organic products and repealing Regulation (EEC) No 2092/91. Official Journal of the European Union L.189/1-23. Retrieved 2017 March 15 from eur-lex.europa.eu/LexUriServ/ LexUriServ.do?uri=OJ:L: 2007:189:0001:0023:EN:PDF.

Dorman HJ, Kosar M, Kahlos K, Holm Y, Hiltunen R (2003). Antioxidant properties and composition of aqueous extracts from Mentha species, hybrids, varieties and cultivars. Journal of Agricultural and Food Chemistry 51:4563-4569.

Duriyaprapan S, Britten EJ, Basford KE (1986). The effect of temperature on growth, oil yield and oil quality of corn mint. Annals of Botany 58:729-736.

FAO (2014). FAOSTAT database. Food and Agriculture Organization of the United Nations. Retrieved January 10, 2016 from www.fao.org/faostat/.

Hosoda K, Nishida T, Park WY, Eruden B (2005). Influence of peppermint (Mentha $\times$ piperita L.) Supplementation on nutrient digestibility and energy metabolism in lactating dairy cows. AsianAustralian Journal of Animal Sciences 18(12):1721-1726.

Ibrahim AM, Kainulainen P, Aflatuni A, Tiilikkala K, Holopainen J (2001). Insecticidal, repellent, antimicrobial activity and phytotoxicity of essential oils: with special reference to limonene and its suitability for control of insect pests. Agricultural and Food Science in Finland 10:243-259.

Imai H, Osawa K, Yasuda H, Hamashima H, Arai T, Sasatsu M (2001). Inhibition by the essential oils of peppermint and spearmint of the growth of pathogenic bacteria. Microbios 106:31-39.

Jeliazkova EA, Zheljazkov VD, Craker LE, Yankov B, Georgieva T (1999). NPK fertilizer and yields of peppermint, Mentha $\times$ piperita. Acta Horticulturae 502:231-236.

Karkanis A, Lykas C, Liava V, Bezou A, Petropoulos S, Tsiropoulos N (2017). Weed interference with peppermint (Mentha $\times$ piperita L.) and spearmint (Mentha spicata L.) crops under different herbicide treatments: effects on biomass and essential oil yield. Journal of the Science of Food and Agriculture 10.1002/jfa.8435.

Khorasaninejad S, Mousavi A, Soltanloo H, Hemmati K, Khalighi A 
(2011). The effect of drought stress on growth parameters, essential oil yield and constituent of peppermint (Mentha piperita L.). Journal of Medicinal Plant Research 5:5360-5365.

McKay D, Blumberg JB (2006). A review of the bioactivity and potential health benefits of peppermint tea (Mentha piperita L.). Phytotherapy Research 20:619-633.

Meamarbashi A (2014). Instant effects of peppermint essential oil on the physiological parameters and exercise performance. Avicena Journal of Phytomedicine 4(1):72-78.

Meamarbashi A, Rajabi A (2013). The effects of peppermint on exercise performance. Journal of the International Society of Sports Nutrition 10:15.

Mitchell AR, Yang CL (1998). Irrigation of peppermint for optimal yield. Soil Science Society of America Journal 62:1405-1409.

Montes-Belmont R, Carvajal M (1998). Control of Aspergillus flavus in maize with plant essential oils and their components. Journal of Food Protection 61:616-619.

Németh-Zámbori É, Szabó K, Pluhár Z, Radácsi P, Inotai K (2016). Changes in biomass and essential oil profile of four Lamiaceae species due to different soil water levels. Journal of Essential Oil Research 28:391-399.

Piccaglia R, Dellacecca V, Marotti M, Giovanelli E (1993). Agronomic factors affecting the yields and the essential oil composition of peppermint (Mentha $\times$ piperita L.). Acta Horticulturae 344:29-40.
Rita P, Animesh DK (2011). Seasonal variations in fatty acids from nonpolar lipids of developing peppermint leaves. International Research Journal of Pharmacy 2(8):1-10.

Singh VP, Chatterje BN, Singh DV (1989). Response of mint species to nitrogen fertilization. The Journal of Agricultural Science 113:267271.

Verma RK, Chauhan A, Verma RS, Rahman LU, Bisht A (2013). Improving production potential and resources use efficiency of peppermint (Mentha piperita L.) intercropped with geranium (Pelargonium graveolens L. Herit ex Ait) under different plant density. Industrial Crops and Products 44:577-582.

Zheljazkov VD, Cerven V, Cantrell CL, Ebelhar WM, Horgan T (2009). Effect of nitrogen, location, and harvesting stage on peppermint productivity, oil content, and oil composition. HortScience 44(5):1267-1270.

Zheljazkov VD, Cantrell CL, Astatkie T, Ebelhar MW (2010). Peppermint productivity and oil composition as a function of nitrogen, growth stage, and harvest time. Agronomy Journal 102(1):124-128. 